\title{
The Nature and Potential Applications of Contextual Definition in Philosophy of Law $^{*}$
}

\author{
VITALY OGLEZNEV \\ Department of the Theory and History of the State and Law, Saint Petersburg State University, 7-9 Universitetskaya Emb., Saint \\ Petersburg, 199034, Russia \\ Department of Logic and History of Philosophy, Faculty of Philosophy, Tomsk State University, 36 Lenin Ave., Tomsk, 634050, Russia \\ Email:ogleznev82@mail.ru
}

\begin{abstract}
The paper analyses the nature and potential applications of contextual definitions in modern philosophy of language and jurisprudence. It is shown that the distinction between a contextual definition and a genus-differentia definition proposed by some legal philosophers, where the latter is considered ineffective and unproductive in analyzing legal concepts, is sometimes deceptive. The weaknesses of the argument about this distinction are shown by examining the constitutional legal rules, which can be considered an example of the application of contextual definitions in legal science. On the basis of this claim, it is shown that these two types of definition may well coexist at least in legal language and in some sense complement each other when different areas of their applicability are taken into account.
\end{abstract}

Keywords: contextual definition, genus-differentia definition, context, ordinary language, legal language, rules

\section{INTRODUCTION}

Contextual definition, as opposed to a genus-differentia definition, has become widespread in philosophy literature only in the twentieth century, and this was due to the development of analytic philosophy. The underlying claims to the traditional genus-differentia definition of many analytic philosophers were presented on the basis that this type of definition is neither universal in the sense of de res nor in the sense of de terminus. A genus-differentia definition may be useful when we need to define a particular concept whose genus is already known

\footnotetext{
A draft of this paper was presented at the International Workshop 'On the Nature of Law' at the University of Bremen (Germany) on 23 November 2018, where I benefitted from comments by the participants, especially by Kenneth Himma, Lorenz Kaehler and Dietmar von der Pfordten.

I would like to thank Jean Kollantai for her review of style and the anonymous reviewers who provided extremely helpful and constructive suggestions.

The work on this paper was supported by the Council for Grants of the President of the Russian Federation for State Support of Young Russian Scientists, Award Number MD-137.2020.6, and the Alexander von Humboldt Foundation.
} 
and it remains only to distinguish the class of the objects being defined in this existing genus. What to do when the genus is not known or it cannot be established? One should turn to other methods of definition developed by modern analytic philosophy. Of course, not all such methods - most of which were developed for the needs of other sciences (initially, for logic and mathematics) - can be used in jurisprudence: There are indications that it is not relevant to contextual definition. Moreover, there is a sense that a genus-differentia definition and contextual definition may well coexist at least in legal language and in some sense complement each other, taking into account the different areas of their applicability. I want to argue that these kinds of definition should not be counterposed, but rather can be a unified tool for elucidating legal concepts.

\section{DEFINING A CONTEXTUAL DEFINITION}

Philosophers and legal theorists have long attempted to find a better way to define the concepts we use in our everyday life and legal practice and to establish how this way can be useful. But especially in philosophy (mainly in analytic philosophy) of the 20th century, strong results in developing a theory of definition have been achieved by considering the nature, meaning, and functions of different kinds of definitions (see Reichenbach 1947; Caws 1959; Pap 1964; Brown 1998), their ontological and epistemological features (see Quine 1969; Ayer 1971; Belnap 1993), the problems encountered when applying them (Dubs 1943; Carnap 1966), and how they can increase our knowledge of using language terms and concepts (Robinson 1950; Matthews 1998). Legal philosophers and theorists have also been concerned with defining fundamental legal concepts. The outcomes of their work have led to a better understanding of how legal language operates and have shown that linguistic knowledge can facilitate our understanding of the substance of law. But questions about defining legal concepts did not become central until the publication of H. L. A. Hart's fundamental book The Concept of Law (Hart 1961). Only after it have many legal theorists turned their attention to a theory of definitions (as most representative see Ross 1958; Peczenik 1968; Soper 1983; Birmingham 1984; Jackson 1985; Moles 1987; Bayles 1991; Solan 2006).

But despite the tremendous growth of the theory of definitions in different areas of philosophy, contextual definition itself turned out to be not properly developed in either analytic philosophy or philosophy of law. Although many philosophers and linguists have focused on a contextual definition (see Bacon 1965; Snapper 1974; Brody 1984; Recanati 1986; Reicher 2002; Greimann 2009; Bronzo 2014; and others), even among them, there is no precise understanding of what contextual definitions are. It should be noted (and it would be true) that contextual definitions were not a subject matter of philosophy of law until they were emphasized by Hart (Hart 1954; Hart 1961). His approach to defining fundamental legal concepts (using a truth-conditional definition, or a definition in use) has been recognized for decades and remains fruitful and interesting 'whether as a starting point for new inquiries, as a target for criticism and refutation, or as a general background inspiration' (MacCormick 2008: 214). Because of the length of the article, I will focus in this section solely on the study of the contextual definition given in the works of several philosophers and will not consider other approaches to the theory of definition widely represented in philosophy literature. Such a method may seem incomplete and inconsistent at first glance, but I deliberately limit myself to a description of these approaches as, in my opinion, the most promising ones for better understanding, on the one hand, the differences between a genus-differentia definition and contextual definition, and on the other, the nature of a contextual definition. 
The main focus in analytic philosophy of the 20th century has fallen on the definition in use as a special type of contextual definition. This was partly due to the special scope of such definition in logic and mathematics. But it could be said that J. Bentham anticipated the use of contextual definition. Indeed, as S. Bronzo stated, 'There is a significant continuity between Bentham and subsequent analytic philosophers who either endorse some sufficiently close version of Frege's context principle (such as Frege himself, of course, but also early and later Wittgenstein), or make explicit use of contextual definition (such as Russell and Quine)' (Bronzo 2014: 1). It consists in the fact that the term (or symbol) should be analysed only within the context of its use. In this case, the context demonstrates that the term isolated from it does not perform a denotative function. B. Russell was the first (except perhaps G. Frege) who clearly articulated this in his theory of definite descriptions, which is a typical example of such analysis. For Russell, a definite description, as an incomplete symbol, does not have any meaning in isolation but is only defined in certain contexts. Thus, the logical definition of an incomplete symbol should be contextual: 'Such symbols have what may be called a "definition in use” (Russell, Whitehead 1927: 66). A. J. Ayer described a definition in use more clearly: A symbol is defined in use, not by finding a synonym for it but by demonstrating how the sentences it appears in can be converted into equivalent sentences in which the definiendum and any of its synonyms disappear (Ayer 1971: 49).

A more radical view on the types of definition can be found in H. Reichenbach's Elements of Symbolic Logic. Reichenbach suggests considering on formal grounds only two types: a genus-differentia definition and a definition by coordination of propositions ${ }^{1}$ (analogous to a definition in use) (Reichenbach 1947: 21-22). Modern logic has recognized, he claimed, that in both scientific and conversational languages we often use other forms of definition than a genus-differentia one whose application is very restricted. For example, the meaning of the term 'metabolism' is determined not in a single sentence, but by a set of sentences about the percentage of certain substances contained in someone's blood. If a new term is introduced in this manner, it is not defined explicitly but implicitly, along with other terms. This is a definition by coordination of propositions, which is commonly known as a definition in use (Reichenbach 1947: 22; see also Shapiro 1994: 289-292). The importance of these definitions is that they enable us to define an abstract term by reference to concrete terms, whereas the traditional definition through higher genus and specific difference determines an abstract term by reference to more abstract terms, whereas a genus-differentia definition determines an abstract term by reference to more abstract terms. That is, instead of defining a term apart from the context, we define it in the context of the other terms in conjunction with which it is most often used. For Reichenbach, the definiendum in this definition is a sentence (context) whose basic terms are defined together. Thus, the contextual definitions do not show how the definiendum can be translated into another term, only how a whole sentence containing the definiendum can be translated into sentences that do not contain it (see for more discussion Shapiro 1994; Reicher 2002).

For example, A. Pap held a moderate position and claimed that a contextual definition formally differs from an explicit one in that it is a definition of a term in the context of a sentence (more precisely, statement-form) that involves it (Pap 1964: 51-52). In Pap's view, a contextual definition is especially suitable for terms designating a relationship: a contextual definition of 'brother of' (where 'brother of' is the relation-term) in terms of 'male' and 'parent of' takes the form $X$ is brother of $Y=X$ is a human male distinct from $y$ and the parents of $X$ are the parents of $Y$ (Pap 1964: 52). Therefore, 'syncategorematic' terms can be defined only 
contextually. In a contextual definition, unlike an explicit one, we cannot find a synonym that could substitute, for instance, for the term 'brother of' in sentences like ' $X$ is brother of $Y$ ' or ' $X$ has no brothers. However, if we define the term 'brother of' contextually, then we can translate it into an explicit definition, 'A brother is a male sibling' (see for some criticism Radford 1964; Reicher 2002; and especially Greimann 2009).

On the basis of this very brief overview, we can conclude that contextual definitions are of two types. First, the definition of a term is contextual (in the proper sense) if and only if the definiendum, which contains this term, represents all contexts of its usage; otherwise, a definition is noncontextual. In such a formulation, contextual definition is an explicit definition. Second, definition by context is a definition in which the definiens is a set of some particular contexts (sentences) where the defined term is used. In such a formulation, it is an implicit definition. The difference between these two types of definitions is based on the socalled context dependency. Depending on how we understand the context dependency, we differentiate the contextual definition and definition by context: the former is explicit definition, and the latter is an implicit one (Frege 1960: xxii, 71; see also Dudman 1973; Snapper 1974; Recanati 1986). Further I will focus mainly on the second type, because it fully complies with my approach.

\section{THE USEFULNESS OF CONTEXTUAL DEFINITION IN LEGAL LANGUAGE}

Although legal philosophers have long been concerned with defining fundamental legal concepts, the applicability of a contextual definition approach, which I am first and foremost discussing, is still undeveloped in philosophy of law either as an entire method or as a complete theory. The applicability of contextual definitions and an analysis of their consequences and limitations remain largely poorly delineated in modern philosophy of law. Available studies in this area are more likely to be fragmented, since they focus mainly on certain aspects of the theory of definitions, rather than contextual definitions.

The importance of contextual definitions was put forward by Bentham at the end of the 19th century. He argued that basic legal concepts (such as duty, liberty, claim-right, and others) should not be defined using a genus-differentia definition but by a 'paraphrasis':

A word may be said to be expounded by paraphrasis, when not that word alone is translated into other words, but some whole sentence of which it forms a part is translated into another sentence, whose words are expressive of such ideas as are simple, or are more immediately resolvable into simple ones than those of the former (Bentham 1891: 233).

This method is putting the definiendum in a sentence and then paraphrasing it by transforming the entire sentence into a sentence equivalent in meaning in which the definiendum does not appear. This leads Bentham to the conclusion that the abstract character of most concepts and terms of jurisprudence does not allow us to apply to them the traditional method of a genus-differentia definition (Bentham 1891: 233). In other words, the abstract character of legal concepts requires considering them in a wider context. Paraphrasis, on the one hand, enables us to avoid the difficulties, and on the other, becomes a robust tool in clarifying the meaning of the concepts defined (Bronzo 2014: 5).

In his 'Definition and Theory in Jurisprudence', H. L. A. Hart revived these Bentham's arguments. Like Bentham, Hart claimed that what is needed is: '[S] uch a form of definition that will show how words like that of a "right" derive their meaning from the way in which 
they function in connection with legal rules, for this is what makes them different from ordinary words and hence perplexing' (Hart 1957: 961; see also Coyle 2002; Stewart 2012). The key point of Hart's theory of definition was a suggestion to substitute the traditional method of definition (' $X$ is...') with a new technique that he called explanatory elucidation or a truth-conditional definition: Instead of defining a term, it is necessary to consider a sentence where it operates and is explained, first, by specifying the conditions under which a sentence is true, and second, by how such a sentence is used to draw a conclusion of law in a particular case (Hart 1954: 17, 49).

There were those who took Hart's approach as of 'eminent importance for legal theory' (Ross 1958: 139). A. Ross, who, agreeing with Hart that abstract legal terms have meaning only in context, has offered his improved version of contextual definition. He argued that the decisive factor for explaining the specifics of the definition of legal terms is not that these terms designate certain facts that correspond to the rules, but that they are systematic terms with a purely logical function (Ross 1958: 145). They can be defined only by indicating the rules for a term's use, that is, by specifying the conditions under which sentences in which the term occurs are true. Thus, abstract terms have a meaning only in context. Consider, for example, the expression ' $A$ owns $p$ '. To Ross, this expression is true due to the set of circumstances $F_{1}$, $\ldots \mathrm{F}_{\mathrm{m}}$ (e.g. ' $A$ bought $p$ '), each one of which entails a set of legal consequences $\mathrm{G}_{1}, \ldots \mathrm{G}_{\mathrm{n}}$ (e.g. ' $A$ can reclaim $p$ if it is taken from him by force'). Thus ' $A$ owns $p$ ' is implied by one of the circumstances $F_{1}, \ldots F_{m}$, and that implies, in turn, all the consequences $G_{1}, \ldots G_{n}$. A systematic term, in Ross's view, cannot be defined explicitly, but should be considered in the context of the use (e.g. law enforcement), where it performs a purely logical function.

However, the suggestion to replace a genus-differentia definition with a method that takes into account the conditions of truth (Hart's truth-conditional definition) turned out to be disputable. It is not obvious that Bentham and Hart were talking about the same thing. Hart attributed his theory to Bentham; but it is necessary to ask what exactly Hart adopts from Bentham if he interprets Bentham correctly. Hart, like Bentham, rejects or seems to reject the usefulness of a genus-differentia definition. P. M. S. Hacker, for example, is skeptical of both Bentham's and Hart's definitions being appropriate for the definition of basic legal concepts (Hacker 1969: 347). And he made interesting critical arguments against their positions and demonstrated that Hart's own definition can be proposed in the form of a genus-differentia definition:

For we may say that a legal right (of the kind Hart is concerned with, i.e. a claim-right) is a pair of legal powers, the one being the power to extinguish a legal duty, and the other a power to enforce a legal duty. The genus to which a claim-right belongs is that of a conjunction of legal powers, and it is differentiated from other conjunctions of legal powers by the specific nature of the powers in question (Hacker 1969: 347).

In other words, a definition based on truth conditions can be transformed into a traditional definition in which these truth conditions are preserved. But Hacker's own method of definition can be well transformed into an analytical definition, because before dealing with such a version of a genus-differentia definition we need to somehow establish or determine what legal powers are or what their specific nature is. And soon we will find that we cannot establish a higher genus of a conjunction of legal powers, which is the genus of a claim-right. A contextual definition could (and will) come to the rescue. 
Thus, Hacker's approach can fit well with the position of Hart. It would seem that Hacker would agree with this, because he says that the usefulness or uselessness of any kinds of definition, either paraphrastic or truth-conditional or genus-differentia, depends on the particular purposes we want to achieve (Hacker 1969: 347). I am inclined to think that Hacker here means the same as I do - to differentiate these kinds of definition, the different areas of their applicability must be kept in mind. A quite similar point of view, but with respect to Bentham's approach, can be found in R. Birmingham, who claims that Bentham's statement that a person's right to a thing is 'the relation a man is in with respect to the thing looks like Bentham is defining "right" per genus et differentiam: a right is the relation (genus) a person has to the thing (differentia)' (Birmingham 1984: 784, 795; see for more criticism Moles 1987). But anyway, Hacker's objections to Hart's truth-conditional definition were and still are strong, substantive and sound; it is in fact very hard to find among modern legal philosophers someone who could make an argument against Hart's definition in a more sophisticated way than Hacker has done.

\section{THE SCOPE OF APPLICABILITY OF CONTEXTUAL DEFINITIONS}

As we have seen, the idea of contextual definitions within the framework of legal philosophy has been widely discussed but not well explained. However, Bentham's and Hart's approach - that the contextual definition is opposed to the genus-differentia definition, where the latter is considered ineffective and unproductive in the analysis of fundamental legal concepts - continues to dominate in legal studies. By considering the constitutional legal rules as an example of the application of contextual definitions in jurisprudence, I will show that the argument about this opposition (or more correctly this conflict) is invalid.

My main premise is that the constitutional provisions can be treated as contextual definitions of the basic concepts that are used to formulate specific rules of the legal system, and the Constitution itself can be viewed as a coherent discourse that contextually defines these concepts (for more details see Ogleznev, Surovtsev 2018: 223-226). The idea of axiomatic constructions is that axioms are contextual definitions of the concepts by which they are formulated. It is essential that they, through syntactic relations with other basic concepts used in the formulation of the entire axiomatic system, specify the system of objects to be described to which the given axiomatics can be applied. This type of interpretation of the method of axiomatic construction can be transferred to the understanding of constitutional rules. Here an analogy with the methods of modern deductive sciences may well be useful. In fact, the basic concepts of the legal system, at least logically, appear precisely within the framework of the Constitution. The definition of these concepts cannot go beyond its framework, since this would mean going beyond the legal system itself into the sphere of what is no longer properly a field of law. This in itself suggests that the provisions of the Constitution when formulated use exactly such concepts, the meaning of which should be established within the framework of the Constitution. But this is possible only if we interpret the constitutional rules themselves as a system of contextual definitions of these basic concepts, which generate a syntactically consistent discourse of their use (see Ogleznev, Surovtsev 2018: 222).

Of course, one can propose that there are different ways of stating legal rules in normative legal acts (direct and indirect, referential and blanket, etc.); if a Constitution does not provide for some precision in its concrete articles but stipulates that further precision will be given in other legislative acts, it is because a Constitution gives the 'request' for this further regulation. But this has nothing to do with a suggested approach that the constitutional 
legal rules only could be considered contextual definitions, in which the definiens is a set of some particular contexts (sentences) where the defined term is used. My goal is not to focus on issues of constitutional interpretation, which are more sophisticated than their brief overview, but to offer an example of potential applicability of contextual definitions, where their usefulness can be proved. And it is not a final conclusion, but only a cautious (and still ambitious) assumption, which requires a further detailed study. That is why a constitutional interpretation is not the case here.

This original point of view has not yet become widespread in the legal literature. However, the proposed approach fully complies with the theory of contextual definition and even in a certain sense improves it by introducing new and original characteristics. This understanding of the use of contextual definition of concepts and terms of the Constitution is due to the following circumstances. First, analysing the provisions of the Constitution, we often do not set ourselves the task of finding the specific meaning of a particular term, but we seek to find out only the type of semantic meaning, that is, the scope of its application. The specific meaning of a term is found in other legal statutes that specify and clarify the provisions of the Constitution. Take, for example, Part 3, Article 6 of the Constitution of the Russian Federation, where it is stated, 'A citizen of the Russian Federation may not be deprived of his or her citizenship or of the right to change it'. However, there is nothing here about what the term 'citizenship' means. This term is defined contextually in Part 2, Article 6: 'Every citizen of the Russian Federation shall enjoy in its territory all the rights and freedoms and bear equal duties provided for by the Constitution of the Russian Federation'. Yet an explicit definition of this term is contained in the federal law 'On Citizenship of the Russian Federation': 'Citizenship of the Russian Federation is a stable legal relationship of a person with the State, expressed in a set of their mutual rights and obligations'. Second, by means of contextual definition, we define the term not in isolation, but only in the context where it occurs. For example, Part 1, Article 3 of the Constitution of the Russian Federation, states, 'The bearer of sovereignty and the only source of power in the Russian Federation shall be its multinational people. What is 'sovereignty' here? If we assume the above-discussed arguments, then we find that sovereignty in the sense of Articles 3, 4, 5, 67 and 79 of the Constitution of the Russian Federation implies the supremacy and independence of the state power on its territory and independence in international relations. In this sense, that sovereignty is a necessary qualitative feature of the Russian Federation as a state.

\section{CONCLUSIONS}

In the modern legal literature there are two competing approaches to evaluating the applicability and usefulness of both a contextual definition and a genus-differentia definition of legal concepts. As a summary, we can conclude that a genus-differentia definition could be very useful when we need to define a particular concept whose genus is already known, and therefore it remains only to establish the class of those things that need to be determined using this kind of difference. In particular, such an approach would be justified in relation to definitions of legal concepts and terms used in criminal law, civil law, or administrative law. But when we try to clarify extremely general concepts used in various systems and languages, we should turn to contextual definitions. Such definitions are very useful, for example, when it is necessary to define basic (or fundamental) concepts of the Constitution, the norms of which (and this is their peculiarity) do not assume the existence of what the concepts used in their formulation describe, like 'ideological diversity', 'supreme value, 'privacy,' 'freedom, 'justice,' 'claim-right', etc. 
In this sense, a contextual definition is not a special logical operation, but some characteristic of the context, its relation to the term. As a result, the terms defined contextually become semantically meaningful, and their use in the legal language becomes syntactically consistent.

Received 29 February 2020

Accepted 7 September 2020

\section{References}

1. Ayer, A. 1971. Language, Truth and Logic. Harmondworth: Penguin Books.

2. Bacon, J. 1965. 'An Alternative Contextual Definition for Descriptions', Philosophical Studies: An International Journal for Philosophy in the Analytic Tradition 16(5): 75-76.

3. Bayles, M. 1991. 'Definitions in Law', in Definitions and Definability: Philosophical Perspectives. Synthese Library 216, eds. J. H. Fetzer, D. Shatz, G. N. Schlesinger. Dordrecht: Springer, 251-268.

4. Belnap, N. 1993. 'On Rigorous Definitions', Philosophical Studies: An International Journal for Philosophy in the Analytic Tradition 72(2/3): 115-146.

5. Bentham, J. 1891. A Fragment on Government. Oxford: The Clarendon Press.

6. Birmingham, R. 1984. 'Hart's Definition and Theory in Jurisprudence Again', Connecticut Law Review 16: 775-801.

7. Brody, M. 1984. 'On Contextual Definitions and the Role of Chains', Linguistic Inquiry 15(3): 355-380.

8. Bronzo, S. 2014. 'Bentham's Contextualism and Its Relation to Analytic Philosophy', Journal for the History of Analytical Philosophy 8(2): 1-41.

9. Brown, J. R. 1998. 'What is a Definition?', Foundations of Science 3: 111-132.

10. Carnap, R. 1966. Philosophical Foundations of Physics. An Introduction to the Philosophy of Science. New York, London: Basic Books.

11. Caws, P. 1959. 'The Functions of Definition in Science', Philosophy of Science 26(3): 201-228.

12. Coyle, S. 2002. 'Hart, Raz and the Concept of a Legal System', Law and Philosophy 21(3): 275-304.

13. Dubs, H. 1943. 'Definition and Its Problems', The Philosophical Review 52(6): 566-577.

14. Dudman, V. H. 1973. 'Frege on Definition', Mind, New Series 82(328): 609-610.

15. Frege, G. 1960. The Foundations of Arithmetic: A Logico-Mathematical Enquiry into the Concept of Number. New York: Harper \& Brothers.

16. Greimann, D. 2009. 'Contextual Definitions and Ontological Commitment', Australasian Journal of Philosophy 87(3): 357-373.

17. Hacker, P. M. S. 1969. 'Definition in Jurisprudence', The Philosophical Quarterly 19(77): 343-347.

18. Hart, H. L. A. 1954. 'Definition and Theory in Jurisprudence', Law Quarterly Review 70: 37-60.

19. Hart, H. L. A. 1957. 'Analytical Jurisprudence in Mid-Twentieth Century: A Reply to Professor Bodenheimer', University of Pennsylvania Law Review 105: 953-975.

20. Hart, H. L. A. 1961. The Concept of Law. Oxford: Oxford University Press.

21. Jackson, K. 1985. 'Definition in Legal Reasoning', Jurimetrics 25(4): 377-386.

22. MacCormick, N. 2008. H. L. A. Hart. 2nd edn. Stanford: Stanford University Press.

23. Matthews, A. 1998. A Diagram of Definition. The Defining of Definition. Assen: Van Gorcum.

24. Moles, R. 1987. Definition and Rule in Legal Theory: A Reassessment of H. L. A. Hart and the Positivist Tradition. Oxford: Blackwell Publishers.

25. Ogleznev, V.; Surovtsev, V. 2018. 'The Constitution as an Axiomatic System', Axiomathes 28(2): 219-232.

26. Pap, A. 1964. 'Theory of Definition', Philosophy of Science 31(1): 49-54.

27. Peczenik, A. 1968. 'Juristic Definition of Law', Ethics 78(4): 255-268.

28. Radford, C. 1964. 'Ostensive Definitions, Coordinative Definitions, and Necessary Empirical Statements: A Reply to Arthur Pap', Mind, New Series 73(290): 270-272.

29. Recanati, F. 1986. 'Contextual Dependence and Definite Descriptions', Proceedings of the Aristotelian Society $87:$ : $57-73$.

30. Reichenbach, H. 1947. Elements of Symbolic Logic. London: Macmillan.

31. Reichenbach, H. 1957. The Philosophy of Space and Time. New York: Dover Publications.

32. Reicher, M. 2002. 'Ontological Commitment and Contextual Semantics', Grazer Philosophische Studien 63(1): 141-155.

33. Robinson, R. 1950. Definition. Oxford: Oxford University Press.

34. Ross, A. 1958. 'Definition in Legal Language', Logique Et Analyse 1(3/4): 139-149. 
35. Russell, B.; Whitehead, A. N. 1927. Principia Mathematica. 2nd edn. Vol. 1. Cambridge: Cambridge University Press.

36. Shapiro, L. 1994. "'Coordinative Definition" and Reichenbach's Semantic Framework: A Reassessment', Erkenntnis 41(3): 287-323.

37. Snapper, J. W. 1974. 'Contextual Definition: What Frege Might Have Meant but Probably Didn't', Noûs 3(8): 259-272.

38. Solan, L. M. 2006. 'Definition/Rules in Legal Language', in Encyclopedia of Language \& Linguistics, ed. K. Brown, 2nd edn. Elsevier, 403-409.

39. Soper, P. 1983. 'Legal Theory and the Problem of Definition', The University of Chicago Law Review 50(3): $1170-1200$.

40. Stewart, H. 2012. 'The Definition of a Right', Jurisprudence 3(2): 319-339.

41. Quine, W. V. O. 1969. Ontological Relativity and Other Essays. New York: Columbia University Press.

\title{
Kontekstinio apibrèžimo pobūdis ir taikymo galimybès teisès filosofijoje
}

\begin{abstract}
Santrauka
Straipsnyje analizuojamas kontekstinių apibrèžimų modernioje kalbos filosofijoje ir jurisprudencijoje pobūdis bei taikymo galimybès. Parodoma, kad kai kurių teisès filosofų siūloma perskyra tarp kontekstinio ir genus-differentia apibrèžimų, pastarąji laikant neefektyviu ir neproduktyviu analizuojant teisines sąvokas, kartais klaidina. Argumento už šią perskyrą trūkumai atskleidžiami nagrinejjant konstitucines teisines taisykles, kurias galima laikyti kontekstinių apibrèžimų taikymo teisès moksle pavyzdžiu. Remiantis šiuo teiginiu parodoma, kad abu apibrèžimo tipai gali puikiai koegzistuoti bent jau teisinejje kalboje ir tam tikra prasme papildyti vienas kitą, jei atsižvelgiama ị skirtingas jų pritaikomumo sritis.
\end{abstract}

Raktažodžiai: kontekstinis apibrěžimas, genus-differentia apibrěžimas, kontekstas, kasdienè kalba, teisinè kalba, taisyklès 